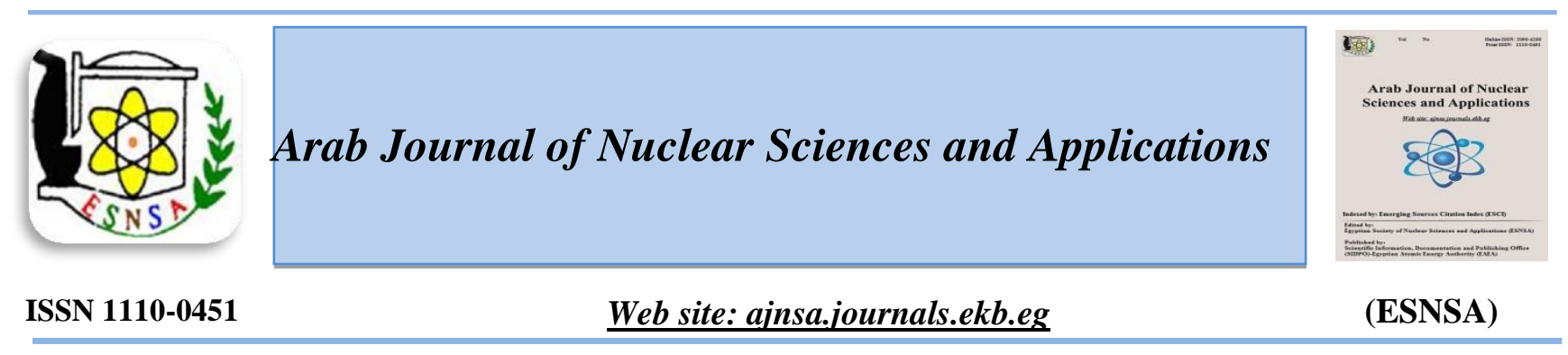

\title{
Evaluation Study for Uranium Adsorption from Gattar Pilot Plant Pregnant Solution by Egyptian Bentonite Sediments
}

\author{
Rania M. Mahdy, and Reda A. Ghazala \\ Nuclear Materials Authority, Cairo, Egypt
}

Received $3^{\text {rd }}$ Jul. 2018 Accepted 23 ${ }^{\text {rd }}$ Nov. 2018

\section{Introduction}

$\mathrm{UO}_{2}{ }^{+2}$ ions represent the uranium (VI) state and are known to form compounds such as uranyl carbonate, uranyl chloride and uranyl sulfate. Several methods are available for removing uranium from aqueous solution, such as chemical precipitation, reverse osmosis, solvent extraction, micelles ultrafiltration, and adsorption. Amongst these methods, adsorption is an attractive method due to its high efficiency, ease of handling, and availability of different adsorbents. Various kinds of new adsorbents for removing and recovering uranium have been reported among which natural clays and their composites are considered as particularly effective, of low-cost, and of chemical stability. Bentonite is a well-defined naturally occurring 2:1 aluminum silicate mineral consisting of one alumina octahedral layer sandwiched between two silica tetrahedral layers [1].
Clay sediments represent excellent natural barriers due to their small grain size, their specific surface area and their digenetic processes (which cause high natural density), besides, their ability to close fissures and cracks (which may form paths for leachates). In addition, their chemical reactivity permits them to immobilize important contaminants i.e. uranium. It is important to note that soil scientists and geochemists knowledgeable of sorption processes in natural environments have long known that generic or default partition coefficient values found in the literature can result in significant errors when used to predict the absolute impacts of contaminant migration or site remediation options. The aim of study was to obtain some necessary data about the adorability and desirability of uranium to be utilized for the

Corresponding author: mariomola.mm@gmail.com

DOI: 10.21608/ajnsa.2018.4302.1101

(C) Scientific Information, Documentation and Publishing Office (SIDPO)-EAEA 
improvement of uranium extraction technology as follows:

1) During the leaching of uranium from its ores, the mineralogical composition of these ores especially the gangue minerals content affects uranium leaching efficiency. Ores having higher clay minerals content are lower in uranium extraction efficiency because they immobilize some uranium. The latter may reach $10 \%$ of the initial uranium content.

2) In the uranium heap leaching process, it is strongly recommended to use clayey layer under the heap to prevent the ground water contamination by the leached uraniferous solution. It is very important to know the suitable clay mineral type, which has the highest uranium absorbability and immobilization and in the same time which one have high affinity with uranium to prevent its losses. Uranium ores, which have higher contents of clay minerals, could face filtration problems during the separation of the spent ore from the leached uranium solution. This is because clay minerals are mostly present in the clayey or silty size and hence block the filter pores. Determination of uranium absorbability by clay minerals will help in developing new methods for desorbing uranium from the spent ores as well as adding special filter aids to solve the solid / liquid separation problem [2].

Due to the increasing concern to guarantee a safe environment by avoiding the environmental pollution problems, it is very important to achieve an effective exploration of geological barriers for suitable disposal sites, especially in radionuclide waste disposal management. Thus, clay sediments represent very good adsorbents having both geological and technical convenience to be landfill barriers. These sediments account an excellent natural barrier due to their ability to close fissures and cracks, their chemical reactivity to immobilize important contaminants like heavy metals and nuclear elements. This target is completely correct with the increasing applications of heap leaching technology in the extractive metallurgy of elements.

Mahdy (2004), [3] Studied the amount of adsorbed uranium on kaoilinite and bentonite and vermiculite sediments from Kalabsha (Aswan), Abu Tartur (Western Desert) and El Hafafite (Eastern Desert) localities. The author proved that the $U$ adsorption increased by increasing the initial concentration of such elements, and proved that $U$ adsorptions is basically depends upon the clay type and the initial concentration of the adsorbed elements. The optimum adsorption conditions in this study were: solid/liquid ratio 1:100, $\mathrm{pH}$ 6-8, while adsorption time ranged from 3-4 hours giving $U$ adsorption maxima 10.52, 14.08 and 11.90 respectively. The obtained adsorption data were found to fit Langmuir isotherm. The aim of the present work is to evaluate the potentiality of Egyptian bentonite clay sediments for uranium adsorption and desorption and to determine their optimum conditions

\section{Experimental \\ Material and methods}

Mechanical and chemical analysis including major and trace elements concentration of a representative technological sample (natural bentonite) collected from EL Sahel El Shamally (North Coast $-\mathrm{H}$ ) West Alexandria, Egypt is in Tables(1\&2), according to Black et al.,( 1985) [4], Wilson,(2004) [5],While uranium solution was kindly received from Gattar pilot plant, Egyptian Nuclear Materials Authority and its complete chemical analysis including major and trace elements was represented in Table(3).

For mineralogical investigation of the study sample, thin slurry of the separated clays placed on a glass slide was air dried at room temperature and subjected to XRD analysis. In the present study, Philips XRD unit (PW3710) with a generator model PW 1830 fitted with a scintillation counter model PW 3020 was used. The XRD tube used was a $\mathrm{Cu}$ target model PW22 33 attached with a Ni -filter. The tube operated at $40 \mathrm{kV}$ and $\mathrm{mA}$. XRD analysis carried out on their clay fraction $(<2$ microns). The identification of the clay minerals was achieved through the XRD pattern using the American Standards and Testing Materials (ASTM) Cards, Index to XRD Powdered Data Files. Scanning Electron Microscope was also used with magnification ranges from $100 \mathrm{x}$ to $1000 \mathrm{x}$ in the ESEM mode. The operating conditions were as follow: resolution equals to $3.5 \mathrm{~nm}$ at $30 \mathrm{KV}, 25$ $\mathrm{nm}$ at $1 \mathrm{KV}$ BSE equals 10.0.

In the Infrared analysis, study sampleswere prepared as pellets using $\mathrm{KBr}$ binding material and subjected to a Bruker vector spectrophotometer 
model FT-IR-22 Germany, in region of 4000-250 $\mathrm{cm}^{-1}$ was used according to Mahdy(2004).[3].

\section{Uranium analysis}

Uranium was determined in the pregnant leach solution, the crude uranium concentrate and in the adsorption experiments using the oxidimetric titration procedure with a standard solution of $\mathrm{NH}_{4} \mathrm{VO}_{3}$ till the appearance of a purplish red colorrepresents the end point [6].Uranium concentration in the working sample solution was calculated according to the following equation:

$\mathrm{U}(\mathrm{g} / \mathrm{L})=\mathrm{T} . \mathrm{V} 1.1000 / \mathrm{V}$

$\mathrm{T}$ : titration intensity of $\mathrm{NH}_{4} \mathrm{VO}_{3}$

V1: consumed $\mathrm{NH}_{4} \mathrm{VO}_{3}(\mathrm{ml})$

$\mathrm{V}$ : Volume of sample $(\mathrm{ml})$

\section{Uranium adsorption process}

Bentonite technological sample preparedfor adsorption experiments which crashed and sewed it $(2 \mathrm{~mm})$, after that some experiments for uranium adsorption were carried out where certain weights of the prepared bentonite sample were agitated with certain volumes of uranium solution. Through these experiments, most factors affecting the adsorption efficiency percent were studied such as (solid/liquid ratio, contact time, $\mathrm{pH}$, temperature and concentration). All uranium adsorption experiments were carried out using $5 \mathrm{~g}$ of the bentonite sample by mixing with $25 \mathrm{~mL}$ of uranium solution and stirring for $2 \mathrm{~h}$ using a mechanical shaker at $175 \mathrm{rpm}$ in the room temperature. After filtration and analysis of uranium adsorption efficiency was determined.

\section{Uranium desorption process}

For this process $5 \mathrm{~g}$ portions of the study sample loaded with uranium were equilibrated with $10 \mathrm{~mL}$ aliquots of $\mathrm{HCl}$ and $\mathrm{NaCl}$ at different concentrations $(0.25,0.5$ and $1 \mathrm{M})$. The suspended materials were shacked for $2 \mathrm{~h}$ at room temperature. After filtration and analysis, uranium desorption efficiency was determined.

\section{Results and Discussion}

Mechanical and chemical characteristics

Table (1) represents the mechanical analysis while Table (2a, b) shows the chemical characteristics of the studied bentonite sediments and chemical characteristics of the pregnant solution.

Table (1): Physical and Chemical characteristics of the study EL Sahel EL Shamally (North Coast H) sediments, Mahdy (2004).[3]

\begin{tabular}{|l|l|l|l|l|}
\hline $\begin{array}{l}\text { Sample } \\
\text { Textural }\end{array}$ & EC & AEC** & CEC $^{*}$ & pH* $^{*}$ \\
\hline Clay & 2.85 & 8.53 & 86.67 & 6.7 \\
\hline
\end{tabular}

- Soil extract 1:5 **AEC for kaoilinite, montmorillonite $=7-20, \quad 20-30 \quad \mathrm{Meq} / 100 \mathrm{~g}$ respectively

$*$ CEC for kaoilinite, montmorillonite $=3-15,60$ $150 \mathrm{Meq} / 100 \mathrm{~g}$ respectively

From this table it could be concluded that:

(1) The textural classes of bentonite sediment belong to clay

(2)Chemical analyses of the extract (1:5) indicated that the study sediments are around neutral, non saline and the values of CEC, AEC are within the range of published data [5].

On the other hand, themineralogical analysis of EL Sahel EL Shamally $(\mathrm{H})$ bentonite sediments shown in XRDpattern, Figure (1) and SEM- EDAX chart Figure(2) reveals that bentonite sample is composed of $48 \%$ Quartz, $11 \%$ kaolinite and $41 \%$ Montmorillonite. 
Table (2a): Chemical composition EL Sahel EL Shamally (H) sediments bentonite sample

\begin{tabular}{llll}
\hline Major Oxides (\%) & & \multicolumn{2}{l}{$\begin{array}{l}\text { Trace } \\
\text { Elements } \\
\text { (ppm) }\end{array}$} \\
\hline $\mathrm{SiO}_{2}$ & 51.2 & $\mathrm{~V}$ & 268 \\
$\mathrm{Al}_{2} \mathrm{O}_{3}$ & 17.30 & $\mathrm{Cr}$ & 115 \\
$\mathrm{TiO} 2$ & 0.93 & $\mathrm{Co}$ & 31 \\
$\mathrm{P} 2 \mathrm{O} 5$ & 0.55 & $\mathrm{Ni}$ & 48 \\
$\mathrm{FeO}$ & 0.12 & $\mathrm{Cu}$ & 33 \\
$\mathrm{Fe} 2 \mathrm{O} 3$ & 4.74 & $\mathrm{Zn}$ & 63 \\
$\mathrm{Na} 2 \mathrm{O}$ & 2.70 & $\mathrm{Ga}$ & 33 \\
$\mathrm{~K} 2 \mathrm{O}$ & 0.67 & $\mathrm{Rb}$ & 111 \\
$\mathrm{CaO}$ & 1.40 & $\mathrm{Sr}$ & 254 \\
$\mathrm{MgO}$ & 1.20 & $\mathrm{Y}$ & 37 \\
$\mathrm{L.O.I}$ & 18.64 & $\mathrm{Zr}$ & 295 \\
$\mathrm{Total}$ & 100.45 & $\mathrm{Nb}$ & 12 \\
& & $\mathrm{Ba}$ & 3483
\end{tabular}

Table (2b): Chemical composition of Gattar pilot plant Pregnant sulfate solution

\begin{tabular}{llll}
\hline Elements & $\begin{array}{l}\text { Conc. } \\
\text { ppm }\end{array}$ & Elements & Conc. ppm \\
\hline $\mathrm{Si}$ & 67 & $\mathrm{Gd}$ & 16 \\
$\mathrm{Al}$ & 19 & $\mathrm{Ba}$ & 2 \\
$\mathrm{P}$ & 89 & $\mathrm{Sr}$ & 16 \\
$\mathrm{Fe}$ & 2311 & $\mathrm{Th}$ & 59 \\
$\mathrm{Ca}$ & 139 & $\mathrm{U}$ & 180 \\
$\mathrm{Mg}$ & 234 & $\mathrm{~V}$ & 8.5 \\
$\mathrm{Na}$ & 165 & $\mathrm{As}$ & 44 \\
$\mathrm{~K}$ & 139 & $\mathrm{Zr}$ & 1 \\
$\mathrm{Cu}$ & 20 & $\mathrm{Y}$ & 21 \\
$\mathrm{Mn}$ & 408 & $\mathrm{La}$ & 15 \\
$\mathrm{Zn}$ & 129 & $\mathrm{Ce}$ & 87 \\
$\mathrm{~Pb}$ & 4 & $\mathrm{Pr}$ & 16 \\
$\mathrm{Mo}$ & 15 & $\mathrm{Nd}$ & 48 \\
$\mathrm{Co}$ & 2 & $\mathrm{Sm}$ & 16 \\
$\mathrm{Cr}$ & 89 & $\mathrm{~Tb}$ & 33 \\
\hline
\end{tabular}




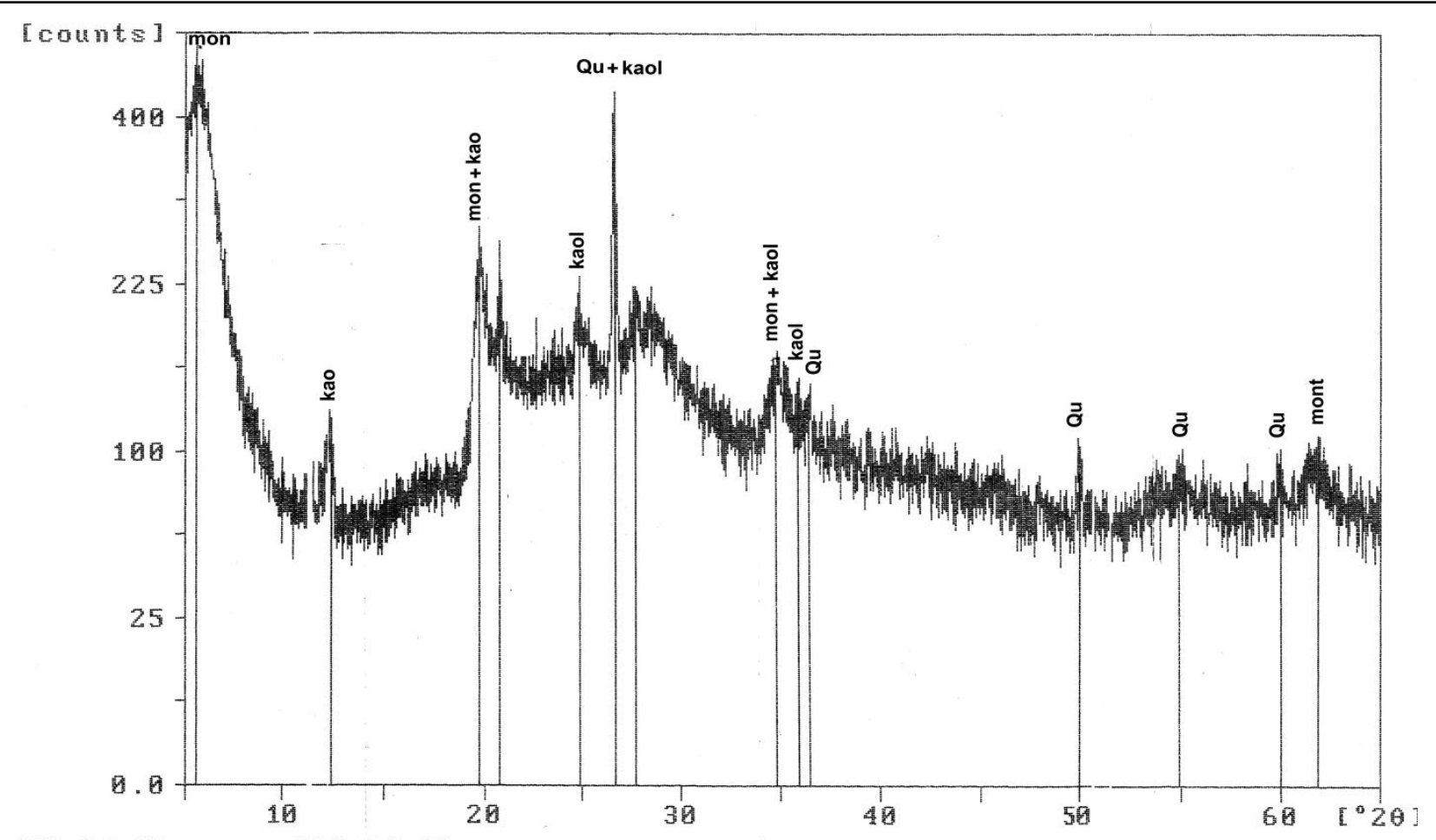

$\mathrm{HAM}-9-\mathrm{D} . \mathrm{RD}$

HIAUII-9-D.DI

Figure (1): XRD pattern of El Sahel el Shamally (H) bentonite sediments

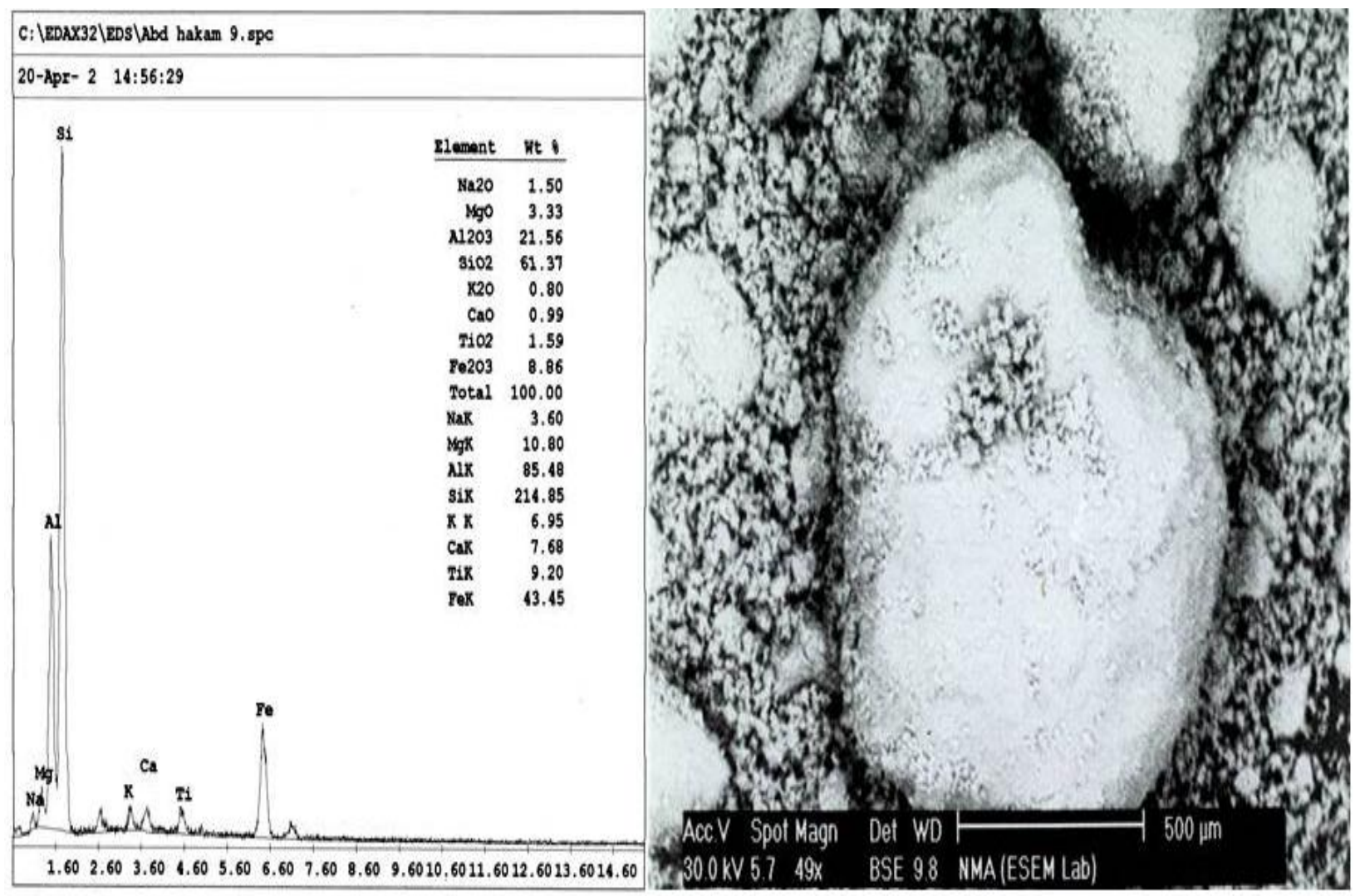

Figure (2): SEM- EDAX of El Sahel EI Shamallybentonite sediments 
Uranium adsorption process

The following effective parameters were studied for achieving the maximum $\mathrm{U}$ adsorption efficiency using natural bentonite

\section{Effect of solid/liquid ratio}

The effect of soiled/liquid ratio (bentonite dose) upon U adsorption using EL Sahel-EL Shamally H bentonite sediments is shown in Figure (3) which indicates that increasing the solid/liquid ratio from 1:1 to1:2 led to increase uranium adsorption efficiency up to $55.1 \%$. Further increasing

Of $S: L$ ratio to $1: 3,1: 5$ and $1: 10$ has an opposite effect where uranium adsorption efficiency decreased down to $21 \%$. The other experimental conditions were fixed at uranium concentration $180 \mathrm{ppm}$, at room temperature; 120min contact time and initial $\mathrm{pH}$. This may be due to increasing the adsorbent amount which may cause aggregation of adsorbent. Consequently, the adsorptive capacity of the available adsorbent was not fully employed at a higher adsorbent amount.

\section{Effect of agitation time}

This effect was already studied in the time range from 30 to $240 \mathrm{~min}$ where the other experimental conditions were fixed at $\mathrm{S} / \mathrm{L}$ ratio of $1: 2$, uranium concentration of $180 \mathrm{ppm}$ at room temperature and the initial solution $\mathrm{pH}$ value. From the obtained data in Figure (4), it can be noticed that the uranium adsorption efficiency increased gradually by increasing the stirring time from 30 to120 $\mathrm{min}$ and then gradually decreased down to the minimum value at $240 \mathrm{~min}$ stirring time.

\section{Effect of $p H$ value on uranium adsorption}

The effect of $\mathrm{pH}$ upon uranium adsorption on EL Sahel - El Shamally $(\mathrm{H})$ bentonite was studied at different $\mathrm{pH}$ values ranging from 1 to 8 of pregnant solution. The other experimental conditions were fixed at the $S / L$ ratio of $1: 2$, the uranium concentration of $180 \mathrm{ppm}$ at room temperature and the contact time $120 \mathrm{~min}$. Figure (5) reveals that, uranium adsorption depends mainly on the acidity of the sulfate solution ( $\mathrm{pH}$ value). Where at low $\mathrm{pH} \leq 4.2$, the number of $\mathrm{H} 3 \mathrm{O}+$ ions exceeds that of the UO2+ several times and the surface is most likely covered with $\mathrm{H} 3 \mathrm{O}+$ ions, reducing the number of binding sites for the adsorption of $\mathrm{UO} 2+2$. At a $\mathrm{pH}$ valuegreater than 4.2 , more $\mathrm{H} 3 \mathrm{O}+$ ions leave the clay mineral surface making the sites available to the cation exchange with the $\mathrm{UO} 22+$ ions and hydrolysis precipitation starts due to the formation of complexes in aqueous solution, i.e., $\quad \mathrm{UO} 2(\mathrm{OH})+, \quad(\mathrm{UO} 2) 2(\mathrm{OH}) 22+$, $(\mathrm{UO} 2) 3(\mathrm{OH}) 53+, \quad(\mathrm{UO} 2)(\mathrm{OH}) 2$, which increase uranium (VI) adsorption [7].Butwhen applied at the real pregnant sample the authors applied the $\mathrm{pH}$ of 4 due prevention of uranium precipitation.

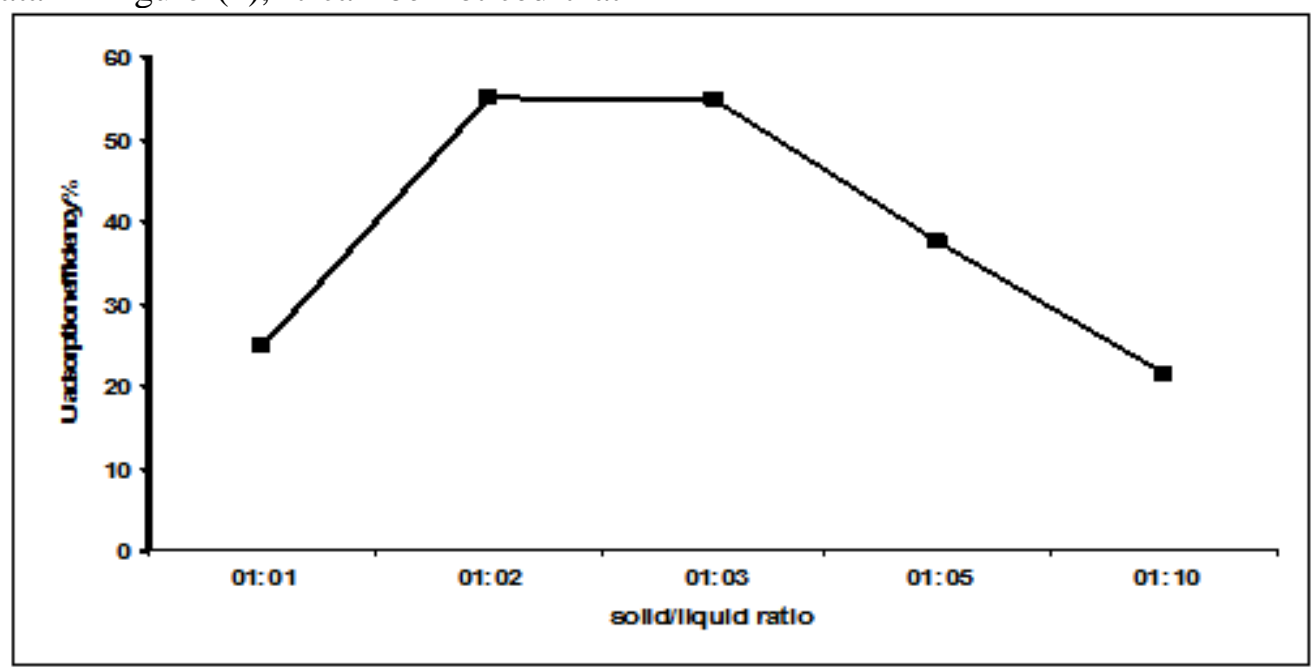

Figure (3): Effect of solid/liquid ratio upon $\mathrm{U}$ adsorption by bentonite sediments 


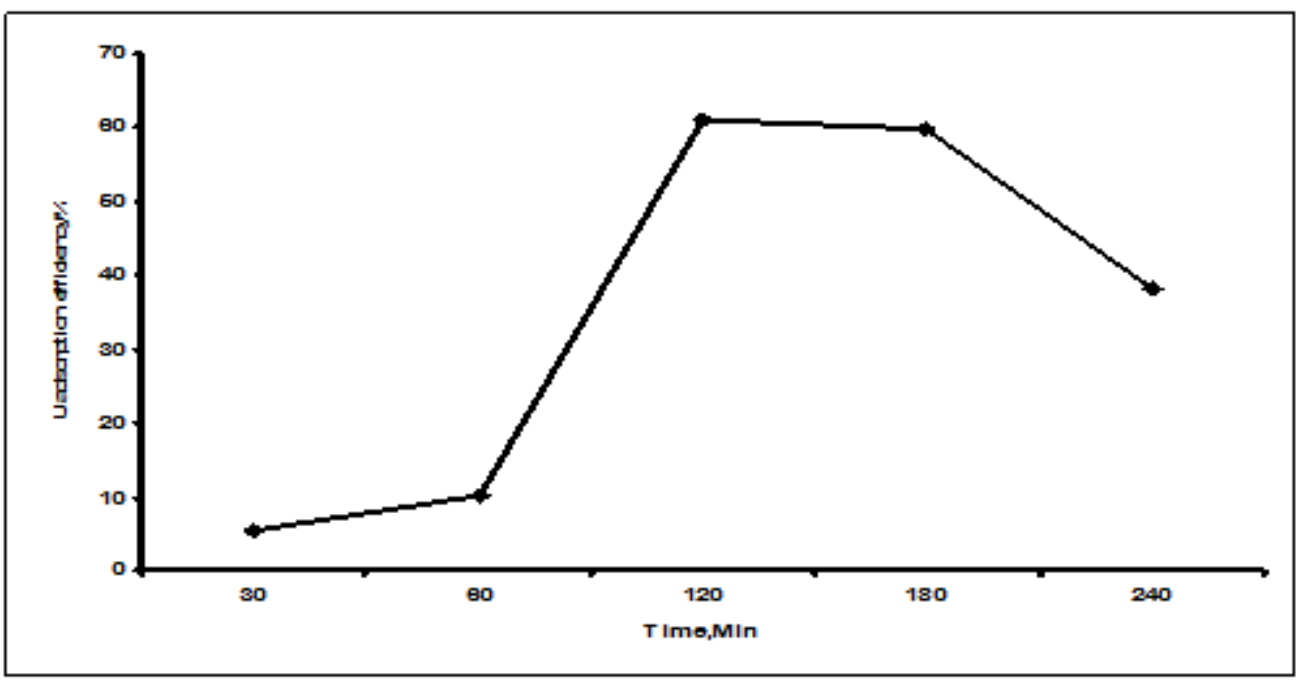

Figure (4): Effect of agitation time upon $U$ adsorption by bentonite sediments

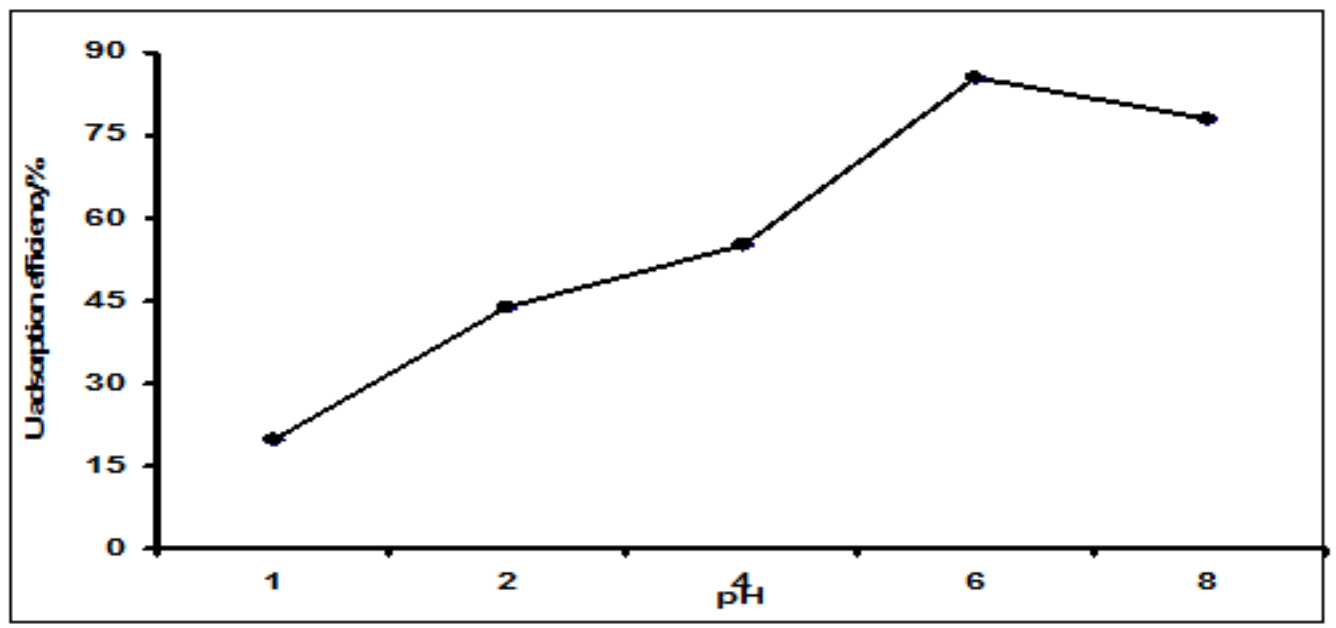

Figure (5): Effect of pH upon $\mathrm{U}$ adsorption by bentonite sediment

\section{Effect of temperature}

This parameter was performed at different temperatures $\left(30,50,70,100,120^{\circ} \mathrm{C}\right)$ where the other experimental conditions were fixed at $\mathrm{S} / \mathrm{L}$ ratio of 1:2, uranium concentration of $180 \mathrm{ppm}$, the contact time $120 \mathrm{~min}$ andpH4.Data presented in Figure (6) emphasizes that increasing temperature from 30 to $120^{\circ} \mathrm{C}$ has an opposite effect on theuranium adsorption efficiency which decreased down to its minimum value. This may be attributed to the breakdown of the formed $\mathrm{U}$ complexes by increasing temperature.

\section{Effect of uranium concentrations}

Results obtained from studying this effect at different concentrations $(50,70,100,120,150$ and180ppm) are shown in Figure (7).Other experimental conditions were fixed at the solid/liquid ratio $1: 2$, the equilibrium time $120 \mathrm{~min}$, $\mathrm{pH} 4$ and $30^{\circ} \mathrm{C}$. These results show that uranium adsorption increases by increasing concentration then decreased.

The increasing trend of sorption at low concentration range in set-1 might be due to strong bonding energies of $U$ with the surface functional groups at sorption sites of soil. On the contrary, when the specific bonding sites become increasingly occupied, sorption becomes unspecific at high concentrations [8].

Arab J. Nucl. Sci. \& Applic. Vol. 52, No. 1 (2019) 


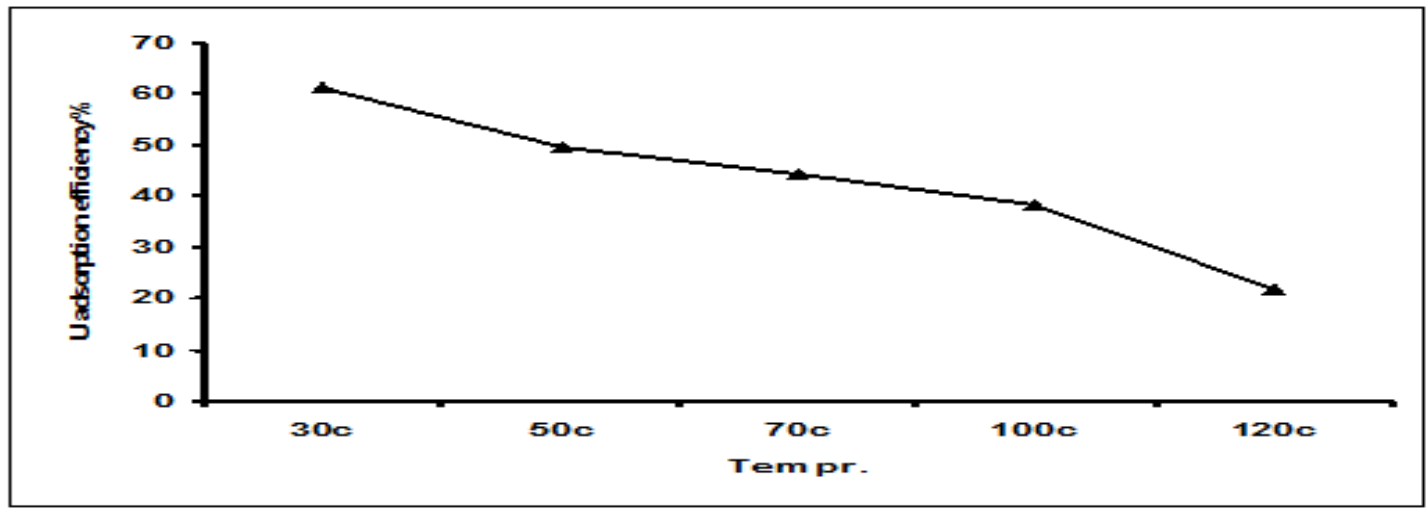

Figure (6): Effect of temperate upon $U$ adsorption by bentonite sediment

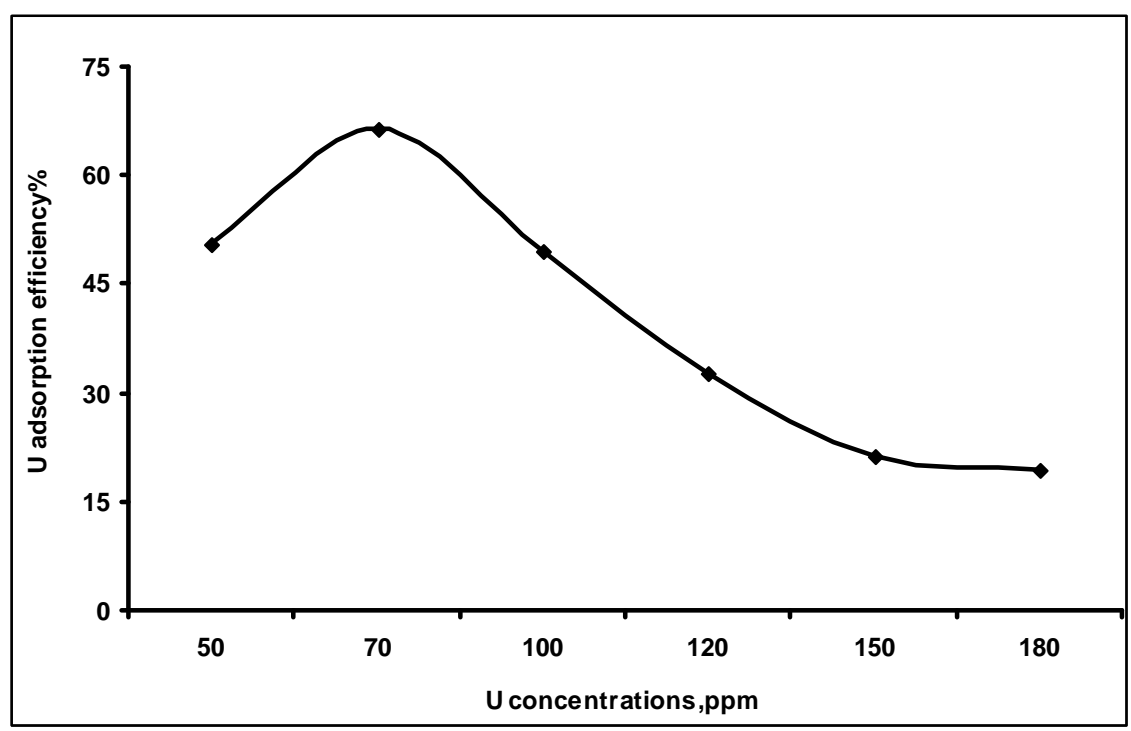

Figure (7): Effect of $\mathbf{U}$ concentrations upon adsorption by bentonite sediments

\section{Uranium desorption process}

Desorption of uranium from the loaded bentonite was applied where different concentrations of $\mathrm{NaCl}(0.25,0.5$ and $1 \mathrm{M})$ and $1 \mathrm{M} \mathrm{HCl}$ were used. Table (3) shows the uranium desorption efficiency percent at different $\mathrm{NaCl}$ concentrations. These experiments were performed at solid/liquid ratio $1 / 2$ for 2 hours and recycled 3 times and $\mathrm{HCl} 1 \mathrm{M} 3$ cycle. This results was agreement with $\mathrm{R}$. Donat and S. Aytas2 (2005). [9].

Table (3): Uranium desorption efficiency from loaded bentonite sediments by $\mathrm{NaCl}$ and $\mathrm{HCl}$

\begin{tabular}{lllll}
\hline \multirow{2}{*}{ Sample } & $\mathbf{0 . 2 5} \mathrm{M}$ & $\mathrm{0.} 5 \mathrm{M}$ & $\mathbf{1 M}$ & $\mathbf{1 M}$ \\
& $\mathrm{NaCl}$ & $\mathrm{NaCl}$ & $\mathrm{NaCl}$ & $\mathrm{HCl}$ \\
\hline \multirow{2}{*}{ Bentonite } & $51 \%$ & $75 \%$ & $69 \%$ & $78 \%$ \\
\hline
\end{tabular}

IR change after adsorption

IR spectroscopy of EL Sahel EL Shamally H sediments sample spectra isillustrated in Figure(8) which reveals that the bentonite sample is characterized by vibrational frequency at $4320 \mathrm{~cm}^{-}$ 1 and $422 \mathrm{~cm}^{-1}$, which are related to the noncrystalline hydrated Al silicate variable composition [10].The changes after uranium adsorption on bentonite sediments are shown in Figure (9) and the main absorption bands are summarized, Table (4). 


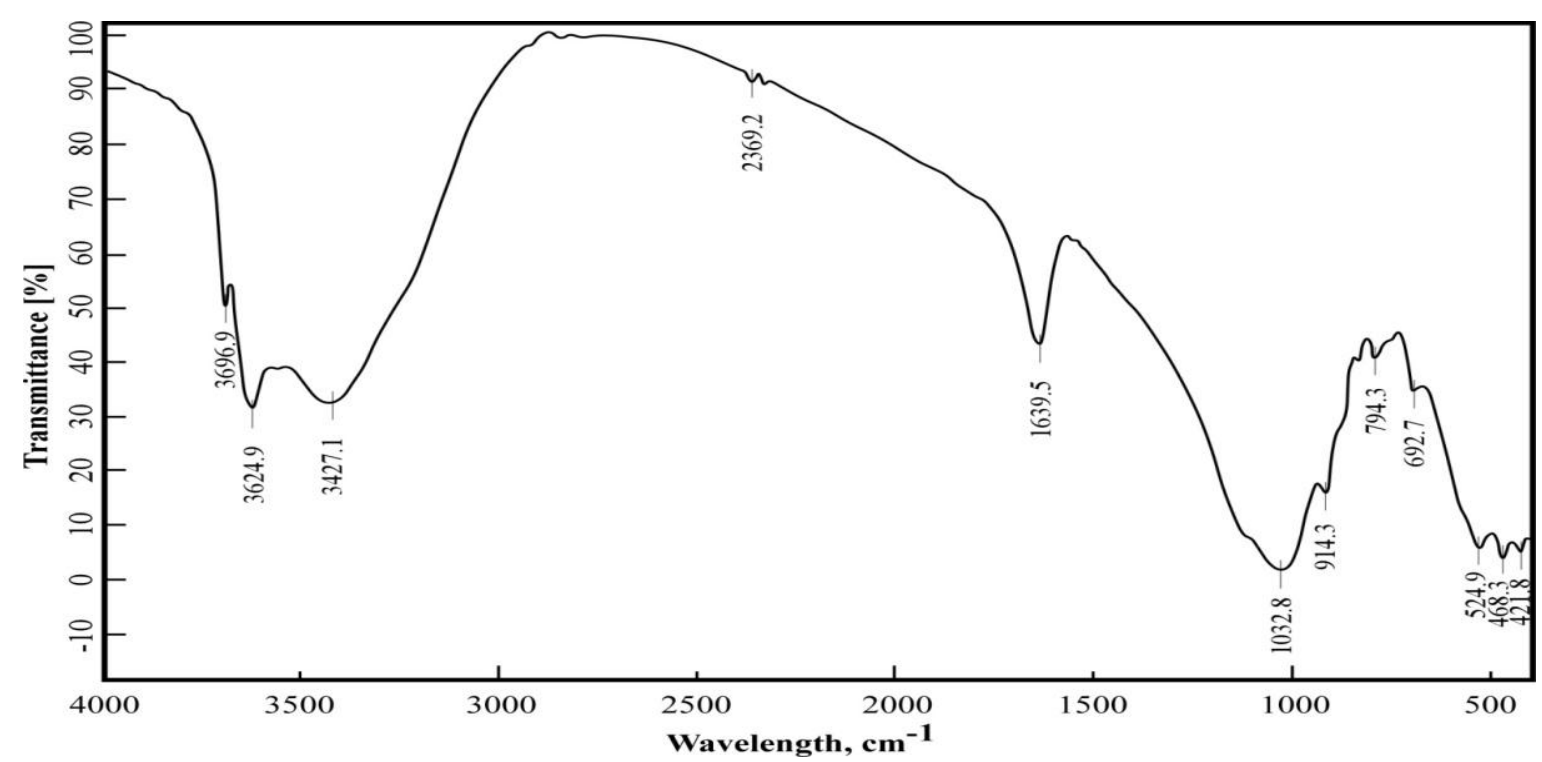

Figure (8): IR spectroscopy of El Sahel El ShamallyBentonite sample

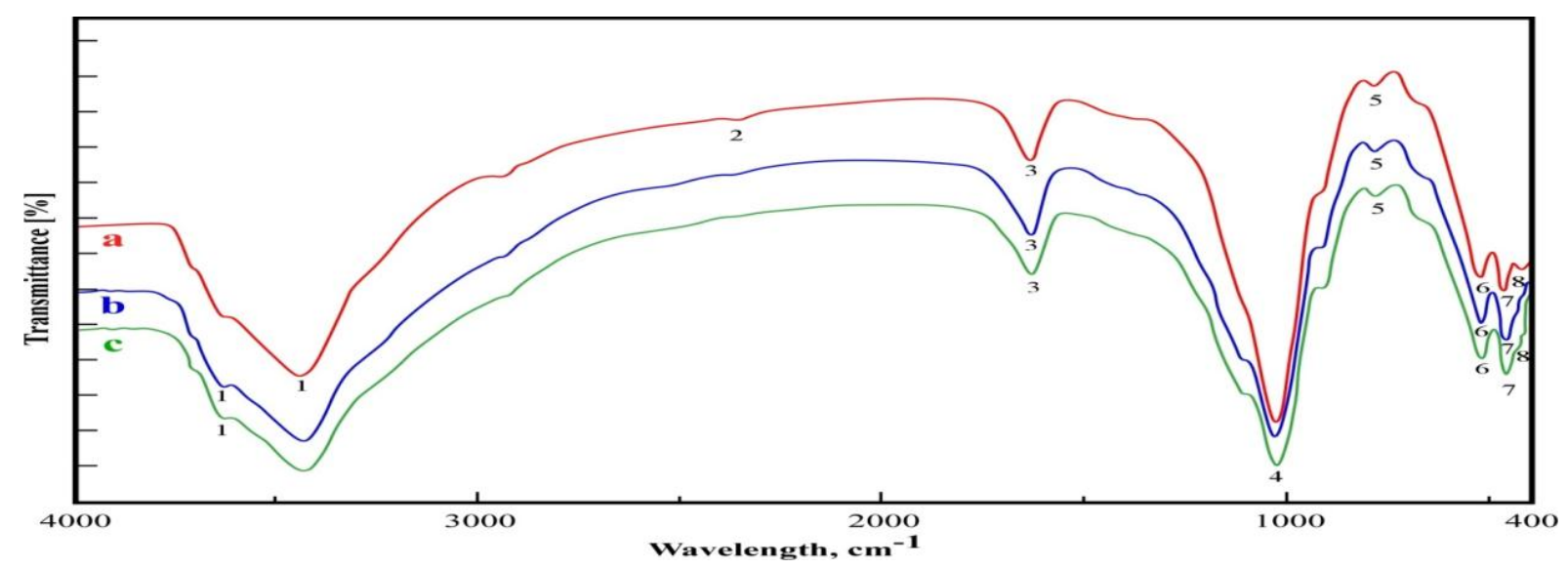

Figure (9): IR spectroscopy of El Sahel El ShamallyBentonite sample after adsorption (1: First adsorption cycle, 2: Second adsorption cycle, 3: Third adsorption cycle)

Table: (4):Mineralogical Changes before and after adsorption of uranium upon bentonite sediments

\begin{tabular}{lll}
\hline $\begin{array}{l}\text { Bands of bentonite before } \\
\text { adsorption }\end{array}$ & $\begin{array}{l}\text { Bands of bentonite after } \\
\text { Adsorption }(\mathbf{1 , 2 , 3})\end{array}$ & Functional Group \\
\hline 3696 & - & OH stretching \\
\hline 3624.9 & - & International Montmorillonite, Muscovite \\
3427.1 & $3423-3427$ & Non crystalline hydrate Al-Silicate[10] \\
2369.2 & 2925 & May be Uranium adsorption.[10] \\
1639 & $1632-1634$ & $\mathrm{H}_{2} \mathrm{O}$ bend \\
1032.8 & $1032.6-1034$ & $\mathrm{C}-\mathrm{O}$ stretching. \\
794 & $788-787$ & May be $\left(\mathrm{UO}_{2}\right)_{2}[\mathbf{1 1}]$ \\
$457-461$ & $464-466$ & May be $\mathrm{Si}-\mathrm{O}$ or Montmorillonite \\
- & 525 & May be U-O group[10] \\
\hline
\end{tabular}




\section{Conclusion}

It is proved that the studied Egyptian clay sediments of bentonite can be used as a geologic barrier suitable for uranium adsorption from its solution. The maximum uranium adsorption efficiency percent was about $70 \%$ while that of desorption was $78 \%$. Theuse of this clay can possibly guarantee a safe environment and minimize the environmental pollution problems.

\section{References}

1- $\quad$ You-Qun Wang $•$ Zhi-bin Zhang $\bullet$ Qin Li $\bullet J$ (2012): "Adsorption of uranium from aqueous solution using HDTMA+-. Pillared bentonite: isotherm, kinetic and thermodynamic aspects". Radioanal. Nucl. Chem. 293. 231-239

2- Abd-Allah, S.M. El Hussaini, O.M. and Mahdy, R.M, (2009): "Disposability of Uranium by Some Clay Sediments in Egypt. Australian Journal of Basic and Applied Sciences, 3(2): 1476-1488.

3- Mahdy, R.M., (2004): "Potentiality of clay minerals to adsorb some elements from nuclear waste materials". M.Sc. Thesis, Faculty of Agricultural, Ain Shams University, Egypt

4- Black C.A., Vans, E., Ensminger, D.D., White, J.L., and Clark, F.E. (1985) Methods of soil analysis, Am. Soc. Agronomy. Int., Madison, Wisconsim, USA, $7^{\text {th }}$ Printing.

5- Wilson, M.J., (1994) Clay mineralogy spectroscopic and chemical determinative methods. Chapman \& Hall, London, New York, Tokyo, 300-327.

6- Davies, W. and Gray, W. (1964): "A rapid and specific titrimetric method for the precise determination of uranium using iron (II) sulphate as reductant; Talanta, 11, 1203-
1211.

7- $\quad$ Youssef W.M., (2017), Uranium Adsorption from Aqueous Solution Using Sodium Bentonite.Chemical Engineering \& Process Technology 8 (4). 2-8

8- Ajay Kumar*, Sabyasachi Rout, Manish Kumar Mishra, RupaliKarpe, PazhayathMana Ravi and Raj Mangal Tripathi, (2015) Impact of particle size, temperature and humic acid on sorption of uranium in agricultural soils of Punjab. Kumar et al. Springer Plus 4:262

9-R. Donat,1 S. Aytas2 (2005). Adsorption and thermodynamic behavior of uranium(VI)on Ulvasp-Na bentonite composite adsorbent. Journal of Radioanalytical and Nuclear Chemistry, Vol. 265, No. 1 (2005) 107.114.

10- Farmer, V.C., (editor) (1974) .The Infra Spectra of Minerals. Mineralogical Soc. London, 383-445.

11- Ray L. Frost ${ }^{\mathrm{a}}$ Kristy L. Erickson ${ }^{\mathrm{a}}$ Jiří Čejka ${ }^{\mathrm{b}} \mathrm{B}$. JagannadhaReddy (2005). A Raman spectroscopic study of the uranyl sulphate mineral johannite. SectrochimicaActa Part A: Molecular and Bimolecular Spectroscopy 61, (11-12), 2702-2707. 